15. Kashuba V, Futornyi S, Andrieieva O, Goncharova N, Carp I, Bondar O, Nosova N. Optimization of the processes of adaptation to the conditions of study at school as a component of health forming activities of primary school-age children Journal of Physical Education and Sport (JPES) 201818(4); 377: 2515-2521.

Цитування на цю статтю:

Кашуба ВА, Холодов СА. Біомеханічні аспекти ходьби дітей молодшого шкільного віку. Вісник Прикарпатського університету. Серія: Фізична культура. 2020 Листоп 24; 36: 9-16

\begin{tabular}{|c|c|}
\hline Відомості про автора: & Information about the author: \\
\hline $\begin{array}{l}\text { Кашуба Віталій Олександрович - доктор наук } 3 \\
\text { фізичного виховання та спорту, професор, Націо- } \\
\text { нальний університет фізичного виховання і спорту } \\
\text { України (Київ, Україна) }\end{array}$ & $\begin{array}{l}\text { Kashuba Vitaliy Oleksandrovych-Doctor of Science } \\
\text { of Physical Education and Sport, Professor, National } \\
\text { University of Ukraine on Physical Education and Sport } \\
\text { (Kyiv, Ukraina) }\end{array}$ \\
\hline \multicolumn{2}{|l|}{$\begin{array}{l}\text { e-mail: Vitaliy_kashuba@ukr.net } \\
\text { https://orcid.org/ 0000-0001-6669-738X }\end{array}$} \\
\hline $\begin{array}{l}\text { Холодов Сердій Анатолійович - кандидат педаго- } \\
\text { гічних наук, доцент, доцент кафедри біології і ос- } \\
\text { нов здоров’я, ДЗ “Південноукраїнський національ- } \\
\text { ний педагогічний університет імені К. Д. Ушин- } \\
\text { ського” (Одеса, Україна) }\end{array}$ & $\begin{array}{l}\text { Kholodov Serhii Anatoliyovych-Candidate Degree in } \\
\text { Pedagogy, Associate professor, Department of Biology } \\
\text { and Heals Fundamentals, State Institution "South } \\
\text { Ukrainian National Pedagogical University named } \\
\text { after K.D. Ushynsky" (Odesa.Ukraina) }\end{array}$ \\
\hline
\end{tabular}
УДК 796: 616.314 Віталій Кашуба, Георгій Ярош, Юрій Крикун, Тамара Хабінець,
doi: 10.15330/fcult.36.16-25 Наталія Домашенко, Андрій Шанковський

\title{
СТАН ПРОСТОРОВОЇ ОРГАНІЗАЦІЇ ТІЛА ЮНИХ СПОРТСМЕНІВ ЯК ПЕРЕДУМОВА РОЗРОБЛЕННЯ Й УПРОВАДЖЕННЯ КОРЕКЦЙ̆НО-ПРОФІЛАКТИЧНИХ ЗАХОДІВ У ТРЕНУВАЛЬНИЙ ПРОЦЕС
}

\begin{abstract}
Мета. Узагальнення теоретичних знань, вітчизняного та зарубіжного досвіду в галузі використання технологій зберігання та коригування здоров'я у процесі підготовки юних спортсменів, а також у визначенні перспектив їхнього застосування за сучасних умов. Методи. Аналіз і систематизація даних науково-методичної літератури, інформаційних ресурсів мережі Інтернет. Результати. На сучасному етапі методика спортивної підготовки позначена втіленням низки радикальних змін, спричинених посиленою конкуренцією на найбільш визнаних у світі змаганнях і актуалізацією тренувальних програм, виконання яких здебільшого вимагає перевищення адаптаџійного потенціалу людського організму. Найбільш нагальною щзоо розв'язання означена проблема постає на початкових етапах багаторічної підготовки дітей і підлітків, специфіку яких складає інтенсивне витрачання резервів їхнього організму на природний ріст і розвиток. Перспективи подальших досліджень убачаємо передусім у розробленні технології профілактики та корекиії порушень просторової організації тіла юних спортсменів. Тому навчально-тренувальні заняття таких спортсменів набудуть не тільки спортивно-результативної, а й оздоровчої спрямованості за умов: урахування під час програмування та конкретного планування засобів спортивного тренування індивідуальних характеристик просторової організації тіла юних спортсменів, рівня їхньої фізичної підготовленості та послідовності виконання ними завдань фізичного вдосконалення. Висновок. Виконання тренувальних навантажень, які перевищують адаптаційний потенціал організму підлітків, інтенсивне витрачання резервів їхнього організму на природний ріст і розвиток й диференціацію фізіологічних систем висуває цілу низку проблем щуодо збереження їх здоров'я. Складність вирішення иієё проблеми посилюють такі фактори, як: рання спеціалізаџія в спорті та негативний вплив на організм щзоденних тренувань з граничними (піковими) фізичними навантаженнями. Відтак, виникають суперечності між підвищеними вимогами до підготовленості юних спортсменів, пов'язаними з потребою систематичного зростання результатів, і обмеженими функціональними можливостями їхнього організму на ранньому етапі онтогенезу.
\end{abstract}

Ключові слова: порушення просторової організації тіла, юні спортсмени, корекційно-профілактичні заходи. 
Aim. Generalization of theoretical knowledge, domestic and foreign experience according use of health preserving and adjustment technologies in young athletes training, as well as determining the prospects for their use in modern conditions. Methods. Data analysis and systematization of scientific and methodical literature, Internet information resources. Results. At the present, the method of sports training demands the implementation of a number of radical changes caused by increased rivalry in the world's most popular competitions, and training programs actualization, that mostly requires adaptive human body potential exceeding. The most urgent problem exist at the initial stages of children and adolescents long-term training, when there is the intensive body's reserves use for natural growth and development. Prospects for further research primarily require the prevention and correction technology development of spatial organization disorders of young athletes body. Therefore, trainings of such athletes will have not only sports-productive, but also health-improving orientation taking into account individual characteristics of young athletes spatial organization while programming and planning sports training means, their physical preparedness level and performance sequence of physical improvement tasks. Conclusion. Trainings that exceeds the adolescents adaptive capacity, the intensive body's reserves use for natural growth and development and physiological systems differentiation put forward for solution a number of problems for their health maintaining. The complexity of solving this problem is exacerbated by such factors as early specialization in sports and the negative impact of daily training with extreme (peak) body loading. Thus, there are contradictions between the increased demands to young athletes training, connected with the need for systematic results increasing, and their limited body functionality at an early ontogenesis stage.

Keywords: disorders of spatial body organization, young athletes, corrective and preventive measures.

Постановка проблеми й аналіз результатів останніх досліджень. Аналіз парадигми введення до наукового обігу та функціонування в царині фізичної культури поняття “просторова організація тіла", представленої у напрацюваннях дослідників [6, 18, 22, 23, 26], слугує підставою для констатації про те, що на сучасному етапі просторову організацію тіла тлумачать як єдність морфологічної та функціональної організації людини, відображену в іï зовнішній формі - “габітусі”, тобто в індивідуальних особливостях біогеометричного профілю постави, функціональному стані опорно-рухового апарату (ОРА) та морфологічному статусі [9, 19, 20, 21, 25].

На основі вивчення широкого спектра наукових студій $[2,5,27]$ постає очевидною інтенсифікація на сучасному етапі динаміки порушень просторової організації тіла юних спортсменів, які займаються різними видами спорту (порушення постави у фротальній і сагітальній площинах становлять від 66 до 71,2\%). Учені $[7,15,24,28]$ визначають порушення величин фізіологічних вигинів хребтового стовпа, гіпермобільність суглобів, поперечну та поздовжню плоскостопість тощо маркерами з'єднувально-тканинних дисплазій, які можуть виступати вагомими детермінантами перевантаження різних відділів ОРА спортсменів, а відтак - зумовлювати виникнення надалі травм і захворювань і власне ОРА, і внутрішніх органів.

Мета дослідження полягає в узагальненні теоретичних знань, вітчизняного та зарубіжного досвіду в галузі використання технологій зберігання та коригування здоров’я у процесі підготовки юних спортсменів, а також у визначенні перспектив їхнього застосування за сучасних умов.

Методи дослідження - вивчення актуальності питання проблем поширеності порушень просторової організації тіла юних спортсменів, передбачали аналіз і систематизацію даних науково-методичної літератури, інформаційних ресурсів мережі Інтернет.

Результати дослідження. На тлі визнання високої актуальності теоретикопрактичних здобутків галузі фізичної культури і спорту з питань обгрунтування тісного зв'язку між станом ОРА та здоров'ям людини $[5,8,9,25]$ дотичні до означеної царини іноземні й українські фахівці виявляють одностайність у баченні відсутності відхилень у стані ОРА як неодмінної умови нормального функціонування органів і систем, розвитку всього організму дітей, зміцнення їхнього здоров'я $[6,7,10]$.

Проведений у такому контексті аналіз карток медичного обстеження представниць спортивних видів гімнастики $[28,29]$ дає підстави стверджувати, що $82 \%$ спортс- 
менок мають порушення постави, серед останніх: $21 \%$ - крилоподібні лопатки; 14,3\% деформація грудної клітки; 5,1\% - сколіотична постава; 1,2\% - остеохондроз; 8,4\% лордотична постава; 32\% - сколіози I та II ступенів. У ході обстеження найбільш частотними порушеннями постави та захворюваннями хребта (50\%) відзначалися художні гімнастки, 20\% - акробатки, 30\% - спортивні гімнастки [6]. Прикметно, що серед представниць художньої гімнастики й акробатики переважають лівобічні сколіотичні порушення ОРА, а в середовищі спортивних гімнасток - правобічні [6].

Л.М. Мелентьєва [14] наголошує на послідовному зростанні частотності виявлення випадків порушень ОРА юних спортсменів різних видів спорту (відхилення постави у фронтальній і сагітальній площинах - у діапазоні 66-71,2\%, сколіотична хвороба - 5,7-11,5\%, плоскостопість - 25-33,9\%). Такі відомості розкривають очевидність того, що на сьогодні індивідуальна специфіка розвитку сполучної тканини, а також функціональні зміни ОРА спортсменів належать до спектра найбільш вагомих проблем сфери юнацького спорту [14].

Так, С.С. Люгайло $[12,13]$ у своєму дослідженні визначає, що зі 151 обстежуваного футболіста (вік - 9-14 років) порушення функції ОРА мали 63 (41,72\%) особи. Крім того, вчений акцентує на домінуванні в загальній структурі діагностованих порушень функціональних форм, виявлених у 34 (53,97\%) обстежених футболістів [12, 13]. Одержані фахівцем [13] дані відображають негативну динаміку показника загальної кількості відхилень стану ОРА залучених до дослідження юних футболістів на прямій дорослішання та професійного становлення: йдеться про діапазон від 30,92\% (вікова група 9-11 років) до 60,98\% (вікова група 14 років).

Л.М. Ярмолинський [17] присвятив своє дослідження простеженню негативної динаміки стану постави юних футболістів (на віковому зрізі 7, 8, 9 років). Зокрема, остання набула такого вияву: серед семирічних спортсменів нормальну поставу демонстрували $66,67 \%$ осіб; восьмирічних спортсменів - 60,66\% осіб; дев'ятирічних спортсменів - 45,65\% осіб. Розподіл типів порушень постави футболістів у віковому діапазоні 7-9 років учений подав так: для семирічних спортсменів найбільш поширеними відхиленнями виявилися кругла спина $(12,50 \%)$, сколіотична постава $(8,33 \%)$ і кругло-увігнута спина $(6,94 \%)$; для восьмирічних спортсменів - кругла спина $(18,03 \%)$ та сколіотична постава $(14,75 \%)$; для дев'ятирічних спортсменів - кругла спина $(15,22 \%) \mathrm{i}$ сколіотична постава $(23,91 \%)[17]$.

Вище названий фахівець [17] також обстоює думку про вплив порушень постави охоплених дослідженням юних футболістів на їхні гоніометричні показники. Відтак, у семирічних футболістів кут, утворений вертикаллю та лінією, що з'єднує остистий відросток хребця $\mathrm{C}_{\text {VII }}$ iз центром мас голови, тобто кут $\alpha_{1}$, досягав найбільших значень у осіб із плоско-увігнутою круглою спиною - 44,30 $\left(\mathrm{S}=0,20^{\circ}\right)$ i $38,28^{\circ}\left(\mathrm{S}=1,40^{\circ}\right)$ відповідно, із плоскою спиною $-36,42^{\circ}\left(\mathrm{S}=0,50^{\circ}\right)$, зі сколіотичною поставою $-32,48^{\circ}$ $\left(\mathrm{S}=1,80^{\circ}\right)$, 3 нормальною поставою $-32,14^{\circ}\left(\mathrm{S}=0,61^{\circ}\right)$, із кругло-увігнутою спиною $31,44^{\circ}\left(\mathrm{S}=1,54^{\circ}\right)$. Серед восьмирічних футболістів найбільші значення кута $\alpha_{1}$ продемонстрували особи із плоско-увігнутою спиною $-44,65^{\circ}\left(\mathrm{S}=0,09^{\circ}\right)$, плоскою спиною $37,22^{\circ}\left(\mathrm{S}=0,91^{\circ}\right)$, круглою спиною $-37,03^{\circ}\left(\mathrm{S}=0,61^{\circ}\right)$, тоді як особи з кругло-увігнутою спиною $-34,49^{\circ}\left(\mathrm{S}=0,56^{\circ}\right)$; $з$ нормальною поставою $-32,12^{\circ}\left(\mathrm{S}=0,40^{\circ}\right)$, зі сколіотичною поставою $-31,23^{\circ}\left(\mathrm{S}=0,70^{\circ}\right)$. У дев'ятирічних футболістів найвищі середні значення показника кута $\alpha_{1}$ виявилися в осіб із плоско-увігнутою спиною $-44,3^{\circ}\left(\mathrm{S}=1,18^{\circ}\right)$, круглою спиною $-37,20^{\circ}\left(\mathrm{S}=0,30^{\circ}\right)$, плоскою спиною $-36,55^{\circ}\left(\mathrm{S}=0,72^{\circ}\right)$ на противагу особам із типом кругло-увігнутою спиною $-34,26^{\circ}\left(\mathrm{S}=1,17^{\circ}\right)$, 3 нормальною поставою $32,06^{\circ}\left(\mathrm{S}=0,22^{\circ}\right)$, зі сколіотичною поставою $-31,50^{\circ}\left(\mathrm{S}=0,75^{\circ}\right)$ [17].

Твердження про те, що функціональний стан м'язів юних спортсменів із нормальною поставою є вищим порівняно 3 аналогічного віку спортсменами 3 пору- 
шеннями постави $[7,8,11,17]$, ілюструють такі дані: статична витривалість м'язів передньої частини тулуба та ніг семирічних футболістів із нормальною поставою $(104,00 \pm 2,04$ c) є достовірно вищою на відміну від таких самих показників дітей із плоскою спиною $(89 \pm 2,07$ c) і сколіотичною поставою $(88,00 \pm 3,61 \mathrm{c})(\mathrm{p}<0,05)$; статична витривалість м'язів задньої частини тулуба та ніг футболістів вищеназваного віку 3 нормальною поставою $(113,00 \pm 4,22$ с) є достовірно вищою порівняно 3 дітьми з іншими визначеними типами постави, а саме - 3 кругло-увігнутою спиною $(99,00 \pm 3,48$ с) і сколіотичною поставою $(97,00 \pm 5,97$ c) $(\mathrm{p}<0,05)$. Аналогічну тенденцію Л. М. Ярмолинський [17] спостеріг у ході вивчення показників восьмирічних і дев'ятирічних футболістів: достовірні відмінності в рівні вияву статичної рівноваги тіла дослідник установив лише між даними футболістів із нормальною поставою $(11,0 \pm 1,16$ с) та сколіотичною поставою $(6,00 \pm 1,04 \mathrm{c})$ за умови виконання тесту із розплющеними очима $(\mathrm{p}<0,05)[7,8,11,17]$.

На переконання О. Гузак [3], вікову групу спортсменів 12-14 років із нефіксованими порушеннями ОРА варто стратифікувати за спортивними спеціалізаціями на: ігрові види спорту - 68 (29,69\%) осіб; єдиноборства - 54 (23,58\%) особи; циклічні види спорту - 42 (18,34\%) особи; складно координаційні види спорту - 35 (15,28\%) осіб; швидкісно-силові види спорту - 30 (13,10\%) осіб. Цікавим видається зафіксоване авторки домінування за частотністю появи порушень у стані ОРА серед спортсменів 12-14 років представників ігрових видів спорту: під час вивчення типів постави таких спортсменів постало очевидним, що питома вага випадків нефіксованих порушень ОРА в сагітальній площині серед юних спортсменок сягала рівня 78,95\% (плоска спина $23,68 \%$, кругла спина - 55,26\%), юних спортсменів - 40,00\% (плоска спина $-16,67 \%$, кругла спина - 23,33); у фронтальній площині в середовищі юних спортсменок $21,05 \%$, юних спортсменів - 60,00\% [3]. Уточнимо, що 18,42\% спортсменок і 20,0\% спортсменів мали комбіновані відхилення стану біогеометричного профілю постави. Попри це, аналіз показників біогеометричного профілю постави контингенту спортсменів у віковому діапазоні $12-14$ років не увиразнив статистично значущою ( $>0,05)$ різниці показників спортсменів і спортсменок із порушеннями вищезгаданого профілю постави в сагітальній і фронтальній площинах [3]. Додамо, що середньо групова оцінка стану біогеометричного профілю постави спортсменок (12-14 років) у сагітальній площині була 11,$25 ; 1,17$ бала, у фронтальній площині - 9,25; 0,89 бала, а узагальнена оцінка - 20,5; 1,69 бала, тоді як відповідна оцінка стану біогеометричного профілю постави спортсменів (12-14 років) виявилася нижчою: в сагітальній площині - на 0,58 бала, тобто на 5,16\%, у фронтальній площині - на 0,08 бала, тобто на $0,86 \%$, а узагальнена оцінка - на 0,66 бала, тобто на 3,22\%. Співзвучні вищеназваним відмінності розкриває також порівняння оцінок стану біогеометричного профілю постави юних спортсменів із відхиленнями в сагітальній площині: відмінності складають 5,33\%, тобто 0,46 бала; 4,50\%, тобто 0,35 бала; 4,94\%, тобто 0,81 бала із переважанням дівчат [3].

Описані дані юних спортсменів (жіночої та чоловічої статей) не дають змоги стверджувати про середній рівень стану їхнього біогеометричного профілю постави. Крім того, особливо негативним фактом варто визнати те, що спортсмени 12-14 років із порушеннями постави в сагітальній площині - обох статей - мають низький рівень стану біометричного профілю постави [3].

Дослідження уможливило отримання таких даних: 57, тобто $35 \%$, залучених до експерименту спортсменів 12-14 років із порушеннями постави демонструють середній, а решта - низький рівні стану біогеометричного профілю постави. Однак $8,82 \%$ обстежуваних у ході експерименту із установленим середнім рівнем стану біогеометричного профілю постави перебувають у так званій “зоні ризику” появи фіксованих порушень постави [В. Кашуба, Р. Бибик, Н. Носова, 2012; М. Дудко, 2016; С. Савлюк, 
2018; I. Випасняк, 2019]. Вивчення результатів експериментального дослідження, проведеного з використанням шкали рівня стану біогеометричного профілю постави, уможливило констатацію про те, що юні спортсмени з відхиленнями рівня стану біогеометричного профілю постави у фронтальній площині продемонстрували наявність у своєму середовищі $94,44 \%$ осіб із середнім і $5,56 \%$ осіб із низьким рівнями стану біогеометричного профілю постави; юні спортсмени з відхиленнями рівня стану біогеометричного профілю постави в сагітальній площині виявили наявність у своєму контингенті $33,33 \%$ осіб із середнім і $66,67 \%$ осіб із низьким рівнями стану біогеометричного профілю постави. Дисонують із вищеописаними показниками юних спортсменів із порушеннями рівня стану біогеометричного профілю постави відповідні показники юних спортсменок з такими самими відхиленнями: серед обстежуваних спортсменок із порушеннями рівня стану біогеометричного профілю постави відхилення у фронтальній площині відзначалися не такими несприятливими виявами, як відхилення в сагітальній площині, а саме: із загального контингенту респондентів жіночої статі 3 відхиленнями у фронтальній площині $100 \%(\mathrm{n}=8)$ осіб мали середній рівень стану біогеометричного профілю постави, тоді як із експериментованої вибірки з відхиленнями в сагітальній площині тільки $33,33 \%(\mathrm{n}=10)$ осіб продемонстрували середній, а більшість - 66,67\% (n=20) - низький рівні стану біогеометричного профілю постави. Це вказує насамперед на те, що найбільш часто юні спортсмени з низьким рівнем стану біогеометричного профілю постави трапляються в середовищі респондентів-дівчат із відхиленнями в сагітальній площині [3].

У ході дослідження у фокусі уваги опинилися також статистично значуща $(\mathrm{p}<0,05)$ пряма кореляційна залежність оцінок рівнів стану біогеометричного профілю постави спортсменів 12-14 років із порушеннями постави та показників фізичної підготовленості останніх [3].

Зокрема, на рисунку 1 представлено статистично значущі $(\mathrm{p}<0,05)$ кореляційні зв'язки між станом біогеометричного профілю постави спортсменок із відхиленнями постави та статичною рівновагою їхнього тіла [3].

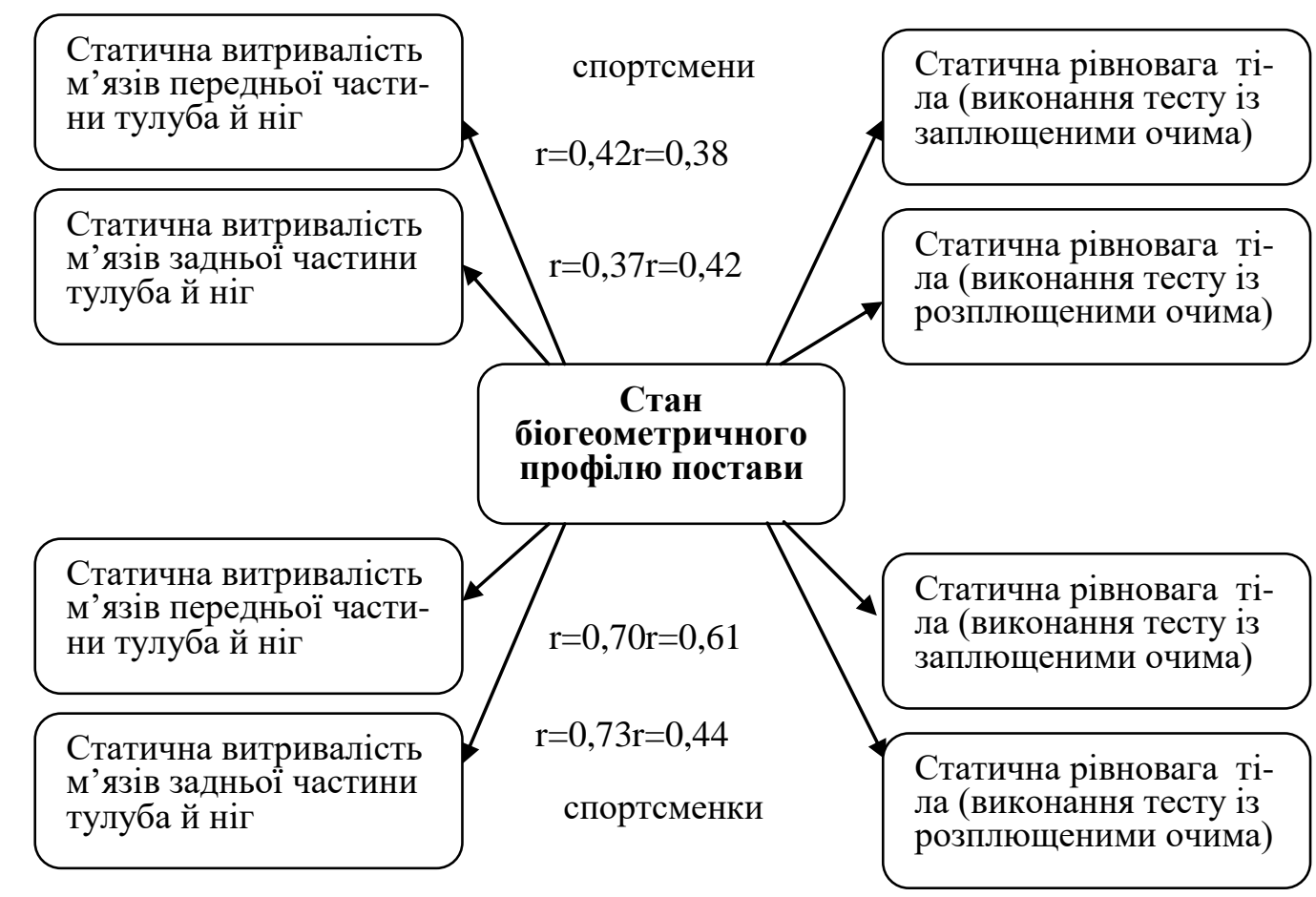

Puc. 1. Кореляційні зв'язки між станом біогеометричного профілю постави та показниками фізичної підготовленості спортсменів 12-14 років із порушеннями постави $(\mathrm{n}=68)$ [3]. 
До таких висновків підштовхують результати виконання спортсменками із порушеннями рівня стану біогеометричного профілю тесту із заплющеними $(\mathrm{r}=0,61)$ та розплющеними $(\mathrm{r}=0,44)$ очима, а також передньої $(\mathrm{r}=0,70)$ та задньої $(\mathrm{r}=0,73)$ частин тулуба й ніг. Експеримент також дав можливість виявити статистично значущі $(\mathrm{p}<0,05)$ кореляційні зв'язки між станом біогеометричного профілю постави таких спортсменок і статичною витривалістю м'язів передньої $(\mathrm{r}=0,42)$ та задньої $(\mathrm{r}=0,37)$ частин тулуба й ніг, а також статичною рівновагою тіла за результатом виконання тесту із заплющеними $(\mathrm{r}=0,38)$ й розплющеними очима $(\mathrm{r}=0,42)$. Авторські дані потрібно вважати переконливим аргументом на користь констатації про потенціал заходів із корекції порушень постави спортсменів 12-14 років у сенсі позитивного впливу на формування та розвиток певних фізичних якостей спортсменів [3].

Передбачений у роботі О. Самойлюк [16] порівняльний експеримент, розгорнутий у площині дослідження опорно-ресорних особливостей стопи хлопчиків 8-9 років, які не займаються спортом, а також хлопчиків, які займаються футболом і баскетболом, полягав у визначенні для хлопчиків 8-9 років, які не займаються спортом, найвищих показників приросту плюснового кута $\alpha$ на рівні 5,17\% (усього $0,94^{0}$ ), для футболістів відповідного віку - на рівні 5,61\% (усього $1,03^{0}$ ), для баскетболістів $-4,42 \%$ (усього $\left.0,79^{0}\right)$, а надалі - в оцінення величини кута $\gamma$, який дає змогу сформувати цілісну картину розвитку опорно-ресорних властивостей стопи хлопчиків 7-10 років. Потрібно акцентувати увагу на тому, що порівняно з хлопчиками, які не займаються спортом, юні спортсмени (ідеться насамперед про баскетболістів) продемонстрували динаміку кута $\gamma$, що розкриває зниження біомеханічних особливостей їхніх стоп [16].

Переконливими аргументами на підтвердження низхідної динаміки стану опорноресорних властивостей стопи досліджуваного О. Самойлюк [16] контингенту дітей варто визнати результати розподілу учасників констатувального експерименту на основі педометричного індексу Фрідланда, що уможливив установлення найбільшої частки спортсменів із нормальною стопою - 60,0\% - серед семирічних футболістів (табл. 1), дещо нижчу - 35,29\% - серед семирічних баскетболістів і ще нижчу - 31,58\% - серед восьмирічних баскетболістів.

Таблиия 1

Результати оцінювання фотограм стопи хлопчиків 7 років на основі методу Фрідланда $(\mathbf{n}=50)[16]$

\begin{tabular}{|c|c|c|c|c|c|c|}
\hline \multirow[t]{3}{*}{ Заняття спортом } & \multicolumn{6}{|c|}{ Розподіл за градаціями форми стопи } \\
\hline & \multicolumn{2}{|c|}{$\begin{array}{c}\text { діти, які не } \\
\text { займаються спортом }\end{array}$} & \multicolumn{2}{|c|}{$\begin{array}{c}\text { юні } \\
\text { футболісти }\end{array}$} & \multicolumn{2}{|c|}{$\begin{array}{c}\text { юні } \\
\text { баскетболісти }\end{array}$} \\
\hline & $\mathrm{n}$ & $\%$ & $\mathrm{n}$ & $\%$ & $\mathrm{n}$ & $\%$ \\
\hline Кількість обстежених & \multicolumn{2}{|c|}{18} & \multicolumn{2}{|c|}{15} & \multicolumn{2}{|c|}{17} \\
\hline Нормальна стопа & 9 & 35,00 & 9 & 60,00 & 6 & 35,29 \\
\hline $\begin{array}{l}\text { Помірна плоскостопість - } \\
\text { знижене склепіння (27-29\%) }\end{array}$ & 7 & 38,89 & 5 & 33,33 & 7 & 41,18 \\
\hline Плоска стопа (25-27\%) & 2 & 11,11 & 1 & 6,67 & 3 & 17,65 \\
\hline $\begin{array}{l}\text { Різка плоскостопість } \\
\text { (менше за 25\%) }\end{array}$ & - & - & - & - & 1 & 5,88 \\
\hline
\end{tabular}

Крім того, у дослідженні О. Самойлюк [16] мінімальну частку осіб із нормальною стопою зафіксовано серед 10-річних баскетболістів, із помірною плоскостопістю 8-річних баскетболістів, а із плоскої стопою - 7-річних футболістів.

3 огляду на вищевикладене й у межах прогнозування наслідків ранньої спеціаліації В.К. Бальсевич запропонував реалізацію методології здоров'язбереження спортсмена, що уможливить забезпечення: 
$\checkmark$ трансформації задуму в цілеспрямований ланцюжок педагогічних впливів, виконуваних відповідно до цільових установок і з набуттям ними форми конкретного очікуваного результату;

$\checkmark$ функціонування технології здоров'язбереження як взаємодетермінованої діяльності тренера, спортсменів, їхніх батьків і соціуму загалом за умови оптимальної реалізації людських ресурсів;

$\checkmark$ уведення до здоров'язберігальних технологій діагностичних методик, спрямованих на визначення спектра показників моторики спортсменів;

$\checkmark$ поетапного проєктування та подальшої реалізації елементів здоров'язберігальних технологій, застосовуваних у будь-якій дитячій спортивній школі [1].

Висновок. На сучасному етапі методика спортивної підготовки позначена втіленням низки радикальних змін, спричинених посиленою конкуренцією на найбільш визнаних у світі змаганнях і актуалізацією тренувальних програм, виконання яких здебільшого вимагає перевищення адаптаційного потенціалу людського організму. Найбільш нагальною щодо розв'язання означена проблема постає на початкових етапах багаторічної підготовки дітей і підлітків, специфіку яких складає інтенсивне витрачання резервів їхнього організму на природний ріст і розвиток. Складність ситуації посилюють такі фактори, як: рання спеціалізація в спорті, інтенсифікація тренувань і їхній негативний вплив на організм людини. Це зумовлює окреслення суперечностей між підвищеними вимогами до підготовленості юних спортсменів, пов'язаними з потребою систематичного зростання результатів, і обмеженими функціональними можливостями їхнього організму на етапі зростання.

1. Бальсевич ВК. Конверсия высоких технологий спортивной подготовки как актуальное направление совершенствования физического воспитания и спорта для всех. Теория и практика физической культуры. 1993; 4: 21-23.

2. Волков ЛВ. Теория и методика детского и юношеского спорта. К.: Олимпийская литература. 2002. $296 \mathrm{c}$.

3. Гузак О. Стан опоно-рухового апарату як передумова розробки сучасних програм фізичної реабілітації. Молодіжний науковий вісник Східноєвропейського національного університету імені Лесі Українки. 2018; 32: 71-78.

4. Кашуба ВА, Паненко НН. К вопросу профилактики нарушения опорно-рессорной функции стопы у юных спортсменов Материалы Международного научного конгресса "Стратегия развития спорта для всех и законодательных основ физической культуры и спорта в странах СНГ”. Кишинев, 2008: 479-481.

5. Кашуба ВА, Яковенко ПА, Хабинец ТА. Технологии, сберегающие и корригирующие здоровье, в системе подготовки юных спортсменов Спортивна медицина. 2008; 2: 140-147.

6. Кашуба В, Сергиенко К, Кондаурова П. Особенности биогеометрического профиля осанки юных спортсменок, специализирующихся в художественной гимнастике PROBLEME ACTUALE ALE METODOLOGIEI PREGATIRI I SPORTIVILOR DE PERFORMANTA. Materialele conferintei stintifice internationale. Chisinau: USEFS, (Молдова). 2010: 163-167.

7. Кашуба ВА, Ярмолинский ЛМ, Хабинец ТА. Современные подходы к формированию здоровьесберегающей направленности спортивной подготовки юных спортсменов Физическое воспитание студентов. 2012; 2: 34-37.

8. Кашуба ВА, Ярмолинский ЛМ. Спортивная подготовка юных спортсменов и её здоровьесберегающая направленность Теория и методика спортивной тренировки. Алматыю. 2013; 1: 30-35.

9. Кашуба ВА, Люгайло СС, Щербина ДВ. Особенности соматической заболеваемости спортсменов на начальных этапах многолетней подготовки: анализ негативных тенденций Теория и методика физической культуры. 2014; 4: 11-25.

10. Кашуба ВА, Люгайло СС. Показатели соматического здоровья юных спортсменов как основа дифференцированного подхода к реализации программ физической реабилитации Теория и методика физической культуры. 2015; 1: 59-79.

11. Кашуба В, Ярмолинский Л, Альошина А, Бичук О, Бичук I. Морфобіомеханічні особливості юних спортсменів на початковому етапі підготовки Молодіжний науковий вісник Східноєвропейського 
національного університету імені Лесі Українки. Фізичне виховання і спорт : журнал / уклад. АВ. Цьось, АІ. Альошина. Луцьк : Східноєвроп. нац. ун-т ім. Лесі Українкию. 2018; 30: 175-184.

12. Кашуба ВО, Люгайло СС,Футорний СМ. Інтеграція програм фізичної реабілітації в процес першого-третього етапів підготовки спортсменів при дисфункціях систем їх організму Спортивна медицина і фізична реабілітація. 2011; 1: 99-112. DOI: https: // doi.org/10.32652/spmed.2019.1.99-112.

13. Люгайло СС. Теоретико-методичні основи фізичної реабілітації при дисфункціях соматичних систем у юних спортсменів в процесі багаторічної підготовки: дис. ... д. фіз. вих. 24.00.03 К., 2017. 460 с.

14. Мелентьева ЛМ. Физическая реабилитация юных спортсменов с нарушениями опорно-двигательного аппарата: автореф. дис. ... канд. мед. наук. 14.00.51. СГМУ. СПб., 2007. 24 с.

15. Рожкова ТА. Корекція порушень постави спортсменів високої кваліфікації у спортивних танцях засобами фізичної реабілітації: автореф. дис. ... канд. фіз. вих. 24.00 .03 К., 2016. 24 с.

16. Самойлюк О, Випасняк I. Ефективність технології корекції порушень біомеханічних властивостей стопи спортсменів на етапі початкової підготовки, з використанням засобів фізичної реабілітації. Молодіжний науковий вісник Східноєвропейського національного університету імені Лесі Українки. 2019; 36: 30-8.

17. Ярмолинський ЛМ. Корекція порушень постави у футболістів на етапі початкової підготовки: автореф. дис. ...канд. фіз. вих. 24.00.01. Дніпро, 2018. 22 с.

18. Kashuba V, Nosova N, Kolomiets T. Technology of biogeometric profile control of children posture in senior preschool age during physical rehabilitation process Journal of Education, Health and Sport. 2017; 7(2): 799-809.

19. Kashuba V, Nosova N, Kozlov Y. Theoretical and methodological foundations of the physical rehabilitation technology of children 5-6 years old, with functional disorders of the support-motional apparatus Journal of Education, Health and Sport. 2017; 7(4): 975-987.

20. Kashuba V, Nosova N. Characteristics of biomechanical properties of child's foot 5-6 years old in the physical rehabilitation process Journal of Education, Health and Sport. 2017; 7(5): 1086-1095.

21. Kashuba V, Lopatskyi S. The control of a state of the static and dynamical posture of a person doing physical exercises Journal of Education, Health and Sport. 2017; 7(4): 963-974.

22. Kashuba V, Lopatskyi S, Vatamanyuk S. The control of a state of the static and dynamical posture of a person doing physical exercises Journal of Education, Health and Sport. 2017; 7(5): 1075-1085.

23. Kashuba V, Lopatskyi S, Lazko O. The control of a state of the static and dynamical posture of a person doing physical exercises Journal of Education, Health and Sport. 2017; 7(8): 1808-1817.

24. Kashuba V, Savlyuk S. Structure and content of the technology of prevention and correction of disturbances of spatial organization of the body of children 6-10 years old with sensory systems deprivation Journal of Education, Health and Sport. 2017; 7(8): 1387-1407.

25. Kashuba V, Lopatskyi S, Prylutska T. Contemporary points on monitoring the spatial organization of the human body in the process of physical education Journal of Education, Health and Sport. 2017; 7(6): 1243-1254.

26. Kashuba V, Andrieieva O, Goncharova N, Kyrychenko V, Karp I, Lopatskyi S, Kolos M. Physical activity for prevention and correction of postural abnormalities in young women Journal of Physical Education and Sport ${ }^{\circledR}$ (JPES). 2019; 19 (73): 500-506.

27. Kashuba V, Andrieieva O, Yarmolinsky L, Karp I, Kyrychenko V, Goncharenko Y, Rychok T, Nosova N. Measures to prevent functional muscular disorders in sports training of 7-9-year-old football players Journal of Physical Education and Sport (JPES). 2020; 20 (52): 366-371. ISSN: 2247 - 806X; p-ISSN: 2247 - 8051; ISSN $-\mathrm{L}=2247-8051$ C JPES.

28. Todorova V, Podhorna V, Bondarenko O, Pasichna T, Lytvynenko Y, Kashuba V. Choreographic training in the sport aerobics Journal of Physical Education and Sport ${ }^{\circledR}$ (JPES). 2019; 19 (6): 2315-2321. Doi: 10.7752/jpes.2019.s6350.

29. Todorova VH, Pogorelova OO, Kashuba VO. Actual Tasks of Choreographic Training in Gymnatic Sports International Journal of Applied Exercise Physiology (IJAEP). 2020; 9 (6): 225-229. ISSN: 2322 - 3537 www.ijaep.com.info@ijaep.com.

\section{References}

1. Balsevich VK. Conversion of high technologies of sports training as an actual direction of improvement of physical education and sports for all. Theory and practice of physical culture, 1993; 4: 21-23.

2. Volkov LV. Theory and methods of children's and youth sports. K.: Olimpiyskaya literatura, 2002. $296 \mathrm{~s}$.

3. Guzak $\mathrm{O}$. The state of the musculoskeletal system as a prerequisite for the development of modern programs of physical rehabilitation. Youth Scientific Bulletin of the Lesia Ukrainka East European National University. 2018; 32: 71-78. 
4. Kashuba VA, Panenko NN. On the issue of prevention of impaired support and spring function of the foot in young athletes Proceedings of the International Scientific Congress "Strategy for the development of sport for all and the legal framework of physical culture and sport in the CIS countries". Chisinau, 2008: 479-481.

5. Kashuba VA, Yakovenko PA, Habinets TA. Technologies that preserve and correct health in the system of training young athletes Sports medicine. 2008; 2: 140-147.

6. Kashuba V, Sergienko K, Kondaurova P. Features of the biogeometric profile of posture of young athletes specializing in rhythmic gymnastics PROBLEMS ACTUALE ALE METHODOLOGIES OF PREGATATION AND SPORTIVILOR DE PERFORMANTA. International synthetic materials. Chisinau: USEFS, (Moldova). 2010: 163-167.

7. Kashuba VA, Yarmolinsky LM, Khabinets TA. Modern approaches to the formation of health-oriented sports training of young athletes Physical education of students. 2012; 2: 34-37.

8. Kashuba VA, Yarmolinsky LM. Sports training of young athletes and its health-oriented orientation Theory and methods of sports training. Almaty, 2013; 1:30-35.

9. Kashuba VA, Lugailo SS, Shcherbina DV. Features of somatic morbidity of athletes at the initial stages of long-term training: analysis of negative trends. Theory and methods of physical culture. 2014; 4: 11-25.

10. Kashuba VA, Lugailo SS. Indicators of somatic health of young athletes as a basis of the differentiated approach to realization of programs of physical rehabilitation Theory and a technique of physical training. 2015; 1: 59-79.

11. Kashuba V, Yarmolinsky L, Alyoshin A, Bychuk O, Bychuk I. Morphobiomechanical features of young athletes at the initial stage of training Youth Scientific Bulletin of the Lesia Ukrainka East European National University. Physical education and sports: magazine / style. AB. This, AI. Alyosha. Lutsk: Eastern Europe. nat. Univ. Lesya Ukrainka, 2018; 30: 175-184.

12. Kashuba VO, Lugailo SS, Futorny SM. Integration of physical rehabilitation programs in the process of the first-third stages of training athletes with dysfunctions of their body systems Sports Medicine and Physical Rehabilitation. 2019; 1: 99-112. Doi: https: // doi.org/10.32652/spmed.2019.1.99-112.

13. Lugailo SS. Theoretical and methodical bases of physical rehabilitation at dysfunctions of somatic systems at young sportsmen in the course of long-term preparation: dis. ...d. phys. output: special. 24.00.03. K., 2017. $460 \mathrm{p}$.

14. Melentyeva LM. Physical rehabilitation of young athletes with musculoskeletal disorders: author's ref.... candidate of Bissertation honey. Science. 14.00.51. SSMU. SPb., 2007. $24 \mathrm{~s}$.

15. Rozhkova TA. Correction of posture disorders of highly qualified athletes in sport dances by means of physical rehabilitation: author's ref. dis. ... Ph.D. phys. Output. 24.00.03. K., 2016. 24 p.

16. Samoilyuk O, Vypasnyak I. The effectiveness of technology for the correction of violations of the biomechanical properties of the foot of athletes at the stage of initial training, using the means of physical rehabilitation. Youth Scientific Bulletin of the Lesia Ukrainka East European National University. 2019; 36: 30-8.

17. Yarmolynsky LM. Correction of posture disorders in football players at the stage of initial training: author's ref. dis. ... Ph.D. phys. Output. 24.00.01. Dnipro, 2018. 22 p.

18. Kashuba V, Nosova N, Kolomiets T. Technology of biogeometric profile control of children posture in senior preschool age during physical rehabilitation process Journal of Education, Health and Sport. 2017; 7(2): 799-809.

19. Kashuba V, Nosova N, Kozlov Y. Theoretical and methodological foundations of the physical rehabilitation technology of children 5-6 years old, with functional disorders of the support-motional apparatus Journal of Education, Health and Sport. 2017; 7(4): 975-987.

20. Kashuba V, Nosova N. Characteristics of biomechanical properties of child's foot 5-6 years old in the physical rehabilitation process Journal of Education, Health and Sport. 2017; 7(5): 1086-1095.

21. Kashuba V, Lopatskyi S. The control of a state of the static and dynamical posture of a person doing physical exercises Journal of Education, Health and Sport. 2017; 7(4): 963-974.

22. Kashuba V, Lopatskyi S, Vatamanyuk S. The control of a state of the static and dynamical posture of a person doing physical exercises Journal of Education, Health and Sport. 2017; 7(5): 1075-1085.

23. Kashuba V, Lopatskyi S, Lazko O. The control of a state of the static and dynamical posture of a person doing physical exercises Journal of Education, Health and Sport. 2017; 7(8): 1808-1817.

24. Kashuba V, Savlyuk S. Structure and content of the technology of prevention and correction of disturbances of spatial organization of the body of children 6-10 years old with sensory systems deprivation Journal of Education, Health and Sport. 2017; 7(8): 1387-1407.

25. Kashuba V, Lopatskyi S, Prylutska T. Contemporary points on monitoring the spatial organization of the human body in the process of physical education Journal of Education, Health and Sport. 2017; 7(6): 1243-1254. 
26. Kashuba V, Andrieieva O, Goncharova N, Kyrychenko V, Karp I, Lopatskyi S, Kolos M. Physical activity for prevention and correction of postural abnormalities in young women Journal of Physical Education and Sport ${ }^{\circledR}$ (JPES). 2019; 19 (73): 500-506.

27. Kashuba V, Andrieieva O, Yarmolinsky L, Karp I, Kyrychenko V, Goncharenko Y, Rychok T, Nosova N. Measures to prevent functional muscular disorders in sports training of 7-9-year-old football players Journal of Physical Education and Sport (JPES). 2020; 20 (1): 36-371. online ISSN: 2247 - 806X; p-ISSN: 2247 - 8051; ISSN - L = 2247 - 8051 C JPES.

28. Todorova V, Podhorna V, Bondarenko O, Pasichna T, Lytvynenko Y, Kashuba V. Choreographic training in the sport aerobics Journal of Physical Education and Sport ® (JPES). 2019; 19 (6): 2315-2321. online ISSN: 2247 - 806X; p-ISSN: 2247 - 8051; ISSN - L = 2247 - 8051. DOI:10.7752/jpes.2019.s6350

29. Todorova VH, Pogorelova OO, Kashuba VO. Actual Tasks of Choreographic Training in Gymnatic Sports International Journal of Applied Exercise Physiology (IJAEP) 2020; 9 (6): 225-229. ISSN: 2322 - 3537 www.ijaep.com info@ijaep.com .

\section{Цитування на цю статтю:}

Кашуба ВА, Ярош Г, Крикун Ю, Хабінець Т, Домашенко Н. Шанковський АЗ. Стан просторової організації тіла юних спортсменів як передумова розроблення й упровадження корекційно-профілактичних заходів у тренувальний процес. Вісник Прикарпатського університету. Серія: Фізична культура. 2020 Листоп 24; 36: 16-25

\begin{tabular}{|c|c|}
\hline Відомості про автора: & Information about the author: \\
\hline $\begin{array}{l}\text { Кашуба Віталій Олександрович - доктор наук з } \\
\text { фізичного виховання та спорту, професор, Націо- } \\
\text { нальний університет фізичного виховання і спорту } \\
\text { України (Київ, Україна) }\end{array}$ & $\begin{array}{l}\text { Kashuba Vitaliy Oleksandrovych - Doctor of Science } \\
\text { of Physical Education and Sport, Professor, National } \\
\text { University of Ukraine on Physical Education and Sport } \\
\text { (Kyiv, Ukraina) }\end{array}$ \\
\hline \multicolumn{2}{|l|}{$\begin{array}{l}\text { e-mail: Vitaliy_kashuba@ukr.net } \\
\text { https://orcid.org/ 0000-0001-6669-738X }\end{array}$} \\
\hline $\begin{array}{l}\text { Ярош Георсій - аспірант, Національний універ- } \\
\text { ситет фізичного виховання і спорту України (Київ, } \\
\text { Україна) }\end{array}$ & $\begin{array}{l}\text { Yarosh Heorhiy - graduate student, National Uni- } \\
\text { versity of Ukraine on Physical Education and Sport } \\
\text { (Kyiv, Ukraina) }\end{array}$ \\
\hline \multicolumn{2}{|l|}{ https://orcid.org/0000-0001-6669-738X } \\
\hline $\begin{array}{l}\text { Крикун Юрій - аспірант, Національний універ- } \\
\text { ситет фізичного виховання і спорту України (Київ, } \\
\text { Україна) }\end{array}$ & $\begin{array}{l}\text { Krykun Yuriy - graduate student, National University } \\
\text { of Ukraine on Physical Education and Sport (Kyiv, } \\
\text { Ukraina) }\end{array}$ \\
\hline \multicolumn{2}{|l|}{ https://orcid.org/0000-0001-6669-738X } \\
\hline $\begin{array}{l}\text { Хабінець Тамара Олександрівна - кандидат педа- } \\
\text { гогічних наук, доцент, Національний університет } \\
\text { фізичного виховання і спорту України (Київ, } \\
\text { Україна) }\end{array}$ & $\begin{array}{l}\text { Khabinets Tamara Oleksandrivna - Candidate of } \\
\text { Science (Education), Associate Professor (Ph. D.), } \\
\text { National University of Ukraine on Physical Education } \\
\text { and Sport (Kyiv, Ukraina) }\end{array}$ \\
\hline \multicolumn{2}{|l|}{$\begin{array}{l}\text { e-mail: kinezio203@gmail.com } \\
\text { https://orcid.org/0000-0002-8098-1181 }\end{array}$} \\
\hline $\begin{array}{l}\text { Домашенко Наталія - старший викладач кафедри } \\
\text { фізичного виховання, Київський національний } \\
\text { економічний університет імені Вадима Гетьмана } \\
\text { (Київ,Україна) }\end{array}$ & $\begin{array}{l}\text { Domashenko Nataliya - senior lecturer at the } \\
\text { Department of Physical Education, Kyiv National } \\
\text { Economic University named after Vadym Hetman } \\
\text { (Kyiv, Ukraina) }\end{array}$ \\
\hline \multicolumn{2}{|l|}{$\begin{array}{l}\text { e-mail: homamari@gmail.com } \\
\text { https://orcid.org/ 0000-0002-4505-6863 }\end{array}$} \\
\hline $\begin{array}{l}\text { Шанковський Андрій Зіновійович - кандидат наук } \\
3 \text { фізичного виховання і спорту, Івано-Франків- } \\
\text { ський національний технічний університет нафти і } \\
\text { газу, (Івано-Франківськ, Україна) }\end{array}$ & $\begin{array}{l}\text { Shankovskyi Andrii Zinoviiovych - Candidate of } \\
\text { Sciences in Physical Education and Sports, Ivano- } \\
\text { Frankivsk National Technical University of Oil and } \\
\text { Gas (Ivano-Frankivsk, Ukraine) }\end{array}$ \\
\hline & \\
\hline
\end{tabular}

